\title{
Exploring Strategic Training Approaches that Lead to The Retention of Talented Employees
}

\author{
Howard G. DeMotta \\ Wayland Baptist University \\ Sonia J. Gonzales \\ Wayland Baptist University \\ Sheron Lawson \\ Wayland Baptist University
}

Training is an important segment of HRM practices, which supports the retention and development of employees because of the training given to employees. This research explored literature on strategic training and development approaches that leads to the retention of talented employees and classifies the different strategic methods into a framework.

\section{INTRODUCTION}

Training is an integral part of various Human Resource Management (HRM) practices, which supports the retention and development of employees because of the different varieties of training given to employees (Anis, Nasir, \& Safwan, 2011; Beaver \& Hutchings, 2005). Researchers (Hays, 1999; Smith \& Cronje, 2002) have argued training and development are the primary retention strategies used by managers in retaining their best employees. Hays (1999) offers a lack of training and development of employees' skill was the most significant determinant of personnel turnover in organizations. However, Bussin (2002) contends that continuous training and development of employee skills can undeniably enable their early turnover instead of reinforcing their retention. Furthermore, providing employees with the latest training and development increases their mobility (Samuel \& Chipunza, 2009).

\section{PROBLEM STATEMENT}

Fishman (1998) claims that there will always be a struggle for talented employees. As such, it becomes increasingly essential for organizations to retain talented and skilled workers to maintain a competitive advantage (Govaerts, Kyndt, Dochy, \& Baert, 2011). Losing talented employees results in a loss of investment since new employees will have to be recruited and trained along with the loss of intellectual capital and the risk of potential loss of confidential information to competitors (Frank, 
Finnegan, \& Taylor, 2004; Walker, 2001). Further, employee training is a complicated human resource practice that can affect the accomplishments of an organization (Jehanzeb \& Bashir, 2013).

\section{PURPOSE AND PROPOSITION}

This paper explores the literature on strategic training and development approaches that lead to the retention of talented employees. The approach reflects classifying the different strategic training and development methods along with constructing a strategic training and development framework to support the retention of talented employees. The significance of the research is to expose the critical understanding of employee strategic training and development practices to enhance the retention of talented employees. The results of the research will better equip HRM practitioners and scholars with supplemental strategic training and development methods for the retention of talented employees along with gathering insightful information that contributes to the theoretical application of the strategic training and development theories.

The following propositions will guide the research:

Proposition 1: An intellectual learning environment will enhance the retention of talented

employees.

Proposition 2: Management development training is necessary to support the retention of talented employees.

\section{REVIEW OF LITERATURE}

Researchers (Anis et al., 2011; Beaver \& Hutchings; 2005; Gering \& Conner, 2002; Govaerts et al., 2011; Ramlall, 2003; Samuel \& Chipunza; 2009; Stahl et al., 2012) have sought to investigate a variety of topics relating to training and development approaches to the retention of a talented workforce. The following literature demonstrates the various concepts of strategic training and development approaches to help garner the retention of talented employees.

\section{Learning Organization Approach}

Learning and development opportunities appear crucial for the retention of talented employees (Arnold, 2005; Hytter, 2007). These opportunities correlate to an organization establishing a supportive learning and working climate. The concept "learning and working climate" is derived from research performed by Abram et al. (2008). In general, the idea refers to the environment wherein employees both learn and work. According to Senge (2006), a learning organization is a place in which people continuously deploy their capabilities and fulfill their correct targets in which new ways of thinking are supported, and new common hopes are delivered.

Noe (2017) suggests the strategic training and development process features modeling a learning organization consisting first of a supportive learning environment. This environment must exist primarily for employees to feel safe to ask questions related to work, processes or if a mistake occurs. When in an actual learning environment, employees are encouraged to take risks, be innovative and explore the untested and unknown to develop new products, processes, and services. The learning processes are also essential for practices where knowledge creation, dissemination, sharing, and the application takes place. Managers reinforcing learning is a pillar in sustaining a learning organization.

Cullen (1999) adds to his argument with Noe (2017), which claims to create a continuous learning opportunity for employees and organizations to thrive in, there must be offers of encouragement, collaboration, and teamwork and an environment that inspires dialogue. Implementing a learning organization leads to a higher problem-solving ability, a value increase of human capital, reduction of risks within decision-making processes, and higher satisfaction of the employees (Luhn, 2016). There is an association between innovation and learning, which Prickett (2017) argues the best solution takes place in a culture where innovative thinking is valued, and where people can take risks in their response to 
produce those solutions by removing them from outside their comfort zones and into new areas to explore.

\section{Misson-orrientation Employee-retention Approach}

Gering and Conner (2002) show a mission-oriented employee-retention strategy that includes a business plan, value proposition, progress measures, and management influence with a focus on management development training. They suggest training is essential to an effective employee retention strategy. The training prepares management to meet and be accountable for specified standards of performance along with developing skills such as coaching, delegating, and communicating. Further, the retention strategy offers a development program that prepares the employee to perform their jobs and to be accountable for their job performance (Gering \& Conner, 2002).

\section{Intellectual Capital Approach}

Research show employers experience difficulty in attracting new employees and struggle in retaining employees (Hale, 1998; Ramlall, 2003). Ramlall (2003) suggest organizations will have to strategically plan and create an intellectual capital environment whereby the exchange of knowledge occurs throughout the organization or risk losing the vital personnel resources that had amass during the employee's tenure with the organization. Also, the organizational environment that reinforces training, rewards, recognition, task identification, career advancements, and flexible work schedules are valued discriminator in the retention strategy to retain its employees along with the appreciation of the employee's career, family, training, and community (Ramlall, 2003).

\section{Strategic HRD Approach}

Researchers (Beaver \& Hutchings, 2005) offer the examination of critical issues in training, development, and education by identifying the emerging problem of significance in Human Resource Development (HRD) and age diversity management that underscores the essential role for strategic human resource management (SHRM) and HRD in small and medium-sized enterprises (SMEs). This proposition suggests that only those that seek a strategic approach to the administration, training, and development of their HR will profit from a competitive position in their market as well as being able to adjust in uncertain conditions (Beaver \& Hutchings, 2005). The research demonstrates HRD increases workforce competence, skills development, and quality, as well as employee motivation and commitment to the organization. Further, organizational learning provides employees with skills in responding to change and an appreciation for lifelong learning (Beaver \& Hutchings, 2005).

\section{Social Learning Approach}

Social learning theory occurs in all organizations since it is based on the behavior and the learning through others. How social learning took place and implemented within an organization are what provides the organization the ability to benefit (Bandura, 1971). The social learning theory is an effective way to engage and adapt to the learning environment by observing the surroundings (Bandura, 1971). Humans are quick to follow others and adjust to the environment by watching and learning by their experiences. Employees seeing behavior from one another, following procedures, building working relationships along with encouragement in the workplace are a large segment of the social learning theory and crucial to the success of the organization (Bandura, 1971).

\section{Government Legislation and Policy Approach}

Research sought to understand the extent to which motivational variables influenced the retention and reduction of employee turnover in both the public and private sector organizations (Samuel \& Chipunza, 2009). The research shows the committed to employee training and development by the South African government. The government developed a comprehensive national skills development system with the help of the legislative and policy to back it up. Such legislation and procedures include the Skills 
Development Act (Act 97 of 1999); the Skill Development Levies Act (Act 9 of 1999); and the National Skills Development Strategy, 2001 (Samuel \& Chipunza, 2009).

\section{Gap and Appreciation Approach}

Govaerts et al. (2011) claim talent leads to exceptional performances, and talented people are often admired and valued. Talent is viewed as a dominant, innate component (Echols, 2007), while factors from the environment, such as education and training, causes talent to emerge (Barab \& Plucker, 2002). Further, since learning and development opportunities appear crucial for the retention of a talented employee, organizations must establish a supportive learning and working climate. This necessity can be described to as appreciation at work, allowance of empowerment and responsibility along with a choice in job tasks and development, challenging and meaningful work, and advancement and development opportunities (Govaerts et al., 2011).

Also, two approaches to learning and working climate exists; the gap approach and the appreciative approach. Finding what is lacking in training should be removed with the introduction of the learning activities. In contrast, the appreciation approach focuses on the finding and enhancing a solution that already is present. Govaerts et al. (2011) stress that when an organization has a desire to retain their employees, it is highly suggested to concentrate on the learning of employees by allowing the employee to engage in doing more and learning more about what they are good at inspires the employee to stay with the organization.

\section{Talent Management Approach}

Stahl et al. (2012) offer Proctor \& Gamble (P\&G) spends one-third to one-half their time developing talent. Consistent with its promote from within policy and its belief that its leadership development apparatus provides a significant source of competitive advantage, talent management permeates P\&G's entire culture. Employees take advantage of leadership development programs during their career tenure. As a strong commitment to leadership development, most companies establish state-of-the-art training centers or learning campuses, which partners with the best universities and educational services providers and the use of the latest leadership development tools and technologies. Also, sophisticated training programs, tools, and practices alone are insufficient, whereby organizations that excel in talent management ensure leadership development is an integral part of the organizational culture and actively involves senior leaders in the process (Stahl et al., 2012).

\section{CONCLUSION}

This paper examined literature on the strategic training and development approaches that led to the retention of talented employees. An assessment of the literature on strategic training and development approaches exposed a variety of themes that relate to the phenomenon of the retention of talented employees. The related ideas provide the emerging characteristics to the following strategic training and development framework that will better equip HRM practitioners and scholars with supplemental strategic training and development methods that leads to the retention of talented employees:

- Conduct a gap approach to find what is lacking in training along with locating and enhancing the training provided.

- Develop policies and procedures directed toward mandating employee training and development tailored explicitly toward the retention of talented employees.

- Develop an HRD program that focuses on workforce competence, skills development, and quality, as well as motivation and commitment to the organization and the development of teams. Organizational learning equips employees with skills to adapt to change and the gratefulness for lifelong learning which reinforces employee retention.

- Develop a management development-training program that prepares managers to be accountable for standards of performance. The core training must focus on developing skills 
such as coaching, delegating, and communicating. Further, demonstrate a strong commitment to leadership development by initiating state-of-the-art training centers or learning campuses that partners with the best universities and educational services providers and the use of the latest leadership development tools and technologies. Also, ensure leadership development is interwoven and is an integral part of the organizational culture that actively involves senior leaders in the process.

- Allow and support a social learning environment where employees can adapt to their surroundings and search for success by observing others while learning through their experiences. Further, the situation must be supportive of learning and the working culture that displays an appreciation at work, allowing empowerment and responsibility while offering a choice in job tasks and development, challenging and meaningful employment, and advancement and development opportunities.

- Strategically plan and create an intellectual learning environment where employees learn and work. The situation must offer encouragement, inspire dialogue, collaboration, and teamwork. The intellectual learning environment allows for the exchange of ideas and innovation with a greater problem-solving aptitude for the employee and the organization.

As previously illustrated in the review of the literature, organizations having a desire to retain their employees will concentrate on the learning of employees by allowing the employee to engage in doing more and learning more about what they are good at, which inspires the employee to remain with the organization. The strategic training and development framework (see Figure 1) offers HRM practitioners and scholars with compulsory supplemental design to support the strategy training and development practice. Lastly, the findings of this study provide an opportunity to ruminate additional offerings to research that develop the research approaches to the theoretical implications of strategic training and development to support the retention of talented employee's literature.

\section{FIGURE 1 \\ STRATEGIC TRAINING AND DEVELOPMENT (T\&D) FRAMEWORK TO RETAIN TALENTED EMPLOYEES}

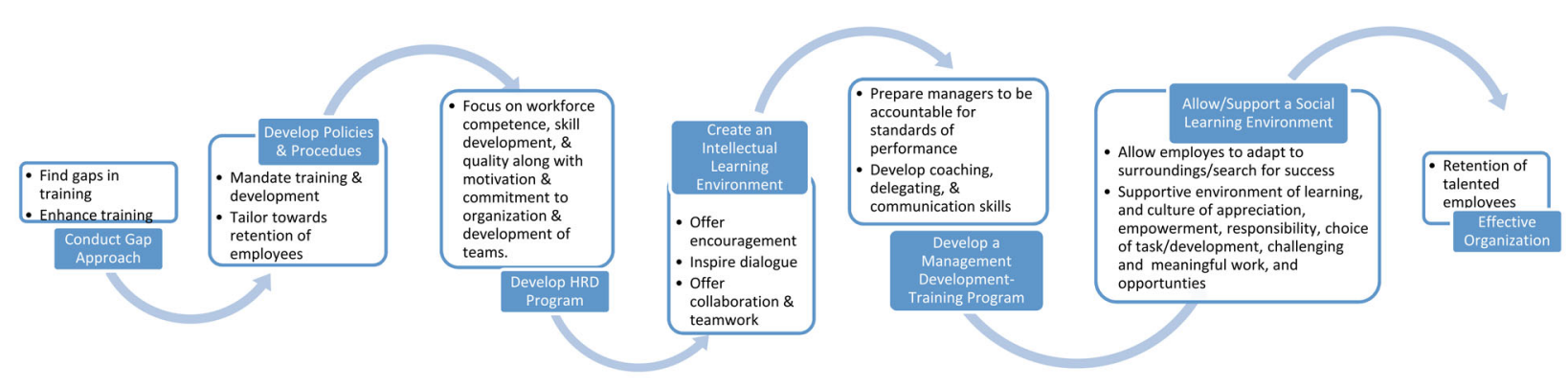




\section{REFERENCES}

Abrams, J., Castermans, S., Cools, H., Michielsen, M., Moeyaert, B., Van Meeuwen, N., \& VanNooten, L. (2008). Leren en talent management: factoren die het behouden van (talentvolle) werknemers beinvloeden. Learning and talent management: factors which influence the retention of (talented) employees"), unpublished research report. Faculty of Psychology and Educational Sciences, University of Leuven, Leuven.

Anis, A., Nasir, A., \& Safwan, N. (2011). Employee retention relationship to training and development: A compensation perspective. African Journal of Business Management, 5(7), 2679-2685.

Arnold, E. (2005). Managing human resources to improve employee retention. The Health Care Manager, 24(2), 132-140

Bandura, A. (1971). Social learning theory. General Learning Corporation. General Learning Press. New York City NY.

Barab, S. A., \& Plucker, J. A. (2002). Smart people or smart contexts? Cognition, ability and talent development in an age of situated approaches to knowing and learning. Educational Psychologist, 37(3), 165-182.

Beaver, G., \& Hutchings, K. (2005). Training and developing an age diverse workforce in SMEs: The need for a strategic approach. Education + Training, 47(8/9), 592-604.

Bussin, M. (2002). Retention strategies: remuneration answers. Knowledge Resources.

Cullen, J. (1999). Socially constructed learning: A commentary on the concept of the learning organization. The Learning Organization, 6(1), 45-52.

Echols, M. E. (2007). Learning's role in talent management. Chief Learning Officer, 6(10), 36-40.

Fishman, C. (1998). The war for talent. Fast Company, 16(8), 104-108.

Frank, F. D., Finnegan, R. P., \& Taylor, C. R. (2004). The race for talent: Retaining and engaging workers in the 21st century. Human Resource Planning, 27(3).

Gering, J., \& Conner, J. (2002). A strategic approach to employee retention. Healthcare Financial Management, 56(11), 40-44.

Govaerts, N., Kyndt, E., Dochy, F., \& Baert, H. (2011). Influence of learning and working climate on the retention of talented employees. Journal of Workplace Learning, 23(1), 35-55.

Hale, J. (1998). Strategic Rewards: Keeping your best talent from walking out the door. Compensation \& Benefits Management, 14(3), 39-50.

Hays, S. (1999). Generation X \& Y and the art of the reward. Workforce, 78(11), 44-48.

Hytter, A. (2007). Retention strategies in France and Sweden. The Irish Journal of Management, 28(1), 59-79.

Jehanzeb, K., \& Bashir, N. A. (2013). Training and development program and its benefits to employee and organization: A conceptual study. European Journal of Business and Management, 5(2).

Luhn, A. (2016). The learning organization. Creative and Knowledge Society, 6(1), 1-13.

Noe, R. A. (2017). Employee training and development (7 Ed). New York: McGraw-Hill Education

Prickett, C. M. (2017). On leading innovation by becoming a learning organization. Comptroller Corner Workforce Connection, 4(3).

Ramlall, S. (2003). A review of employee motivation theories and their implications for employee retention within organizations. Journal of American Academy of Business, 5(1/2), 52-63.

Samuel, M. O., \& Chipunza, C. (2009). Employee retention and turnover: Using motivational variables as a panacea. African Journal of Business Management, 3(9), 410-415.

Senge, P. (2006). The fifth discipline (Revised ed.). New York: Currency Doubleday.

Smith, P. J., \& Cronje, G. D. (2002). Management principles. Lansdowne. Juta and Company Ltd.

Stahl, G., Björkman, I., Farndale, E., Morris, S. S., Paauwe, J., Stiles, P., \& Wright, P. (2012). Six principles of effective global talent management. Sloan Management Review, 53(2), 25-42.

Walker, J. W. (2001). Zero defections? Human Resource Planning, 24(1), 6-8. 